\title{
GERMINATION OF NETLEAF HACKBERRY SEEDS ON THE NORTH SIDES OF BOULDERS: A SHIFT AWAY FROM PATTERNS OF MATURE HACKBERRY DISTRIBUTION?
}

\author{
Michael T. Stevens ${ }^{1,2}$ and Daniel L. Holland ${ }^{1}$
}

\begin{abstract}
Because limited numbers of netleaf hackberry (Celtis reticulata) seedlings are observed in nature, we evaluated patterns of germination of hackberry seeds $(n=2545)$ that we planted near boulders in the Wasatch Mountain foothills. Seeds were followed over 2 growing seasons. Germination rates were very low overall, but significantly more seeds germinated on the north sides of boulders compared to other boulder aspects. That we found higher rates of germination on the north sides of boulders, instead of on the south sides of boulders where mature hackberry shrubs tend to grow, could reflect year-to-year variation in seed germination and seedling survival but is also consistent with a shift away from warmer and drier sites by hackberry in response to climate change.
\end{abstract}

Resumen.-Debido a que en la naturaleza se observa un número limitado de plantas de semillero de almez del oeste (Celtis reticulata), evaluamos los patrones de germinación de las semillas de almez $(n=2545)$ que sembramos cerca de cantos rodados en el piedemonte de la Montaña Wasatch y que monitoreamos durante dos temporadas de cultivo. Las tasas de germinación fueron muy bajas en general, pero una cantidad significativamente mayor de semillas germinó en los lados norteños de los cantos rodados, en comparación con otros lados de los mismos. El hecho de que encontramos mayores tasas de germinación en los lados norte de los cantos rodados (en vez de en los lados sur, donde los arbustos maduros tienden a crecer) podría reflejar la variación anual en la germinación de las semillas y en la supervivencia de las plántulas, pero también se correlaciona con el alejamiento de las plantas de almez de sitios más calientes y secos en respuesta al cambio climático.

Netleaf hackberry (Celtis reticulata) is a deciduous shrub native to western North America that grows in semiarid regions (DeBolt and McCune 1995a). Mature hackberries are often found growing on warm and dry sites with southern aspects (Tisdale 1986) or on the south sides of boulders (Argyle and Stevens 2013), so it would follow that germination and survival rates for seeds and seedlings should be higher on those types of sites. However, young hackberries are uncommon in the wild (DeBolt and McCune 1995b), and Stevens et al. (2016) reported low germination and survival rates in the field. Surprisingly, Stevens et al. (2016) showed that germination rates were actually highest on the relatively cool and shady north sides of boulders instead of on warm and sunny sites where mature hackberries are found. This mismatch between where mature shrubs grow and where their seeds are more likely to germinate could be due to year-to-year variation in weather but could also be symptomatic of the pronounced effects of climate change in western North
America (Fettig et al. 2013) that can make warm and dry sites too extreme to support germination and establishment of hackberry. This study was designed as a follow-up to the Stevens et al. (2016) study to determine whether the germination and seedling survival patterns observed after one growing season were the same for hackberry seeds that have been planted and exposed to field conditions for 2 growing seasons.

In the foothills of the Wasatch Mountains east of Provo, Utah, we planted 25 hackberry seeds near each of the north, west, south, and east sides of 26 boulders ( $n=2600$ seeds) in a manner described in Stevens et al. (2016). The seeds were planted in October 2014. Fifty-five $(2.1 \%)$ of them germinated in the spring of 2015 (Stevens et al. 2016). To assess the germination of the remaining 2545 hackberry seeds 2 springs after they were planted, we returned to the study site on 9 May, 23 May, 6 June, 30 June, 18 July, 22 August, and 7 November 2016. On each of these dates, we counted the number of seedlings near the sides of each

\footnotetext{
${ }^{1}$ Department of Biology, Utah Valley University, Orem, UT 84058

2E-mail: michael.stevens@uvu.edu
} 
TABLE 1 . The total number of hackberry seeds that germinated and seedlings that survived to be counted on 7 sampling dates in 2016. Hackberry seeds were planted on the north, west, south, or east sides of the 26 boulders (see Fig. 1 caption). When appropriate, the results of chi-square tests are provided. See Fig. 1.

\begin{tabular}{|c|c|c|c|c|c|c|c|}
\hline \multirow[b]{2}{*}{ Sampling date } & \multicolumn{4}{|c|}{ Boulder sides } & \multicolumn{3}{|c|}{ Statistics } \\
\hline & North & West & South & East & $\chi^{2}$ & $\mathrm{df}$ & $P$ \\
\hline 9 May & 36 & 28 & 18 & 15 & 11.412 & 3 & 0.010 \\
\hline 23 May & 53 & 53 & 31 & 22 & 18.686 & 3 & $<0.001$ \\
\hline 6 June & 51 & 46 & 37 & 21 & 13.439 & 3 & 0.004 \\
\hline 20 June & 44 & 30 & 18 & 15 & 19.542 & 3 & $<0.001$ \\
\hline 18 July & 19 & 9 & 2 & 4 & 20.353 & 3 & $<0.001$ \\
\hline 22 August & 3 & 2 & 0 & 2 & & & \\
\hline 7 November & 1 & 1 & 0 & 0 & & & \\
\hline
\end{tabular}

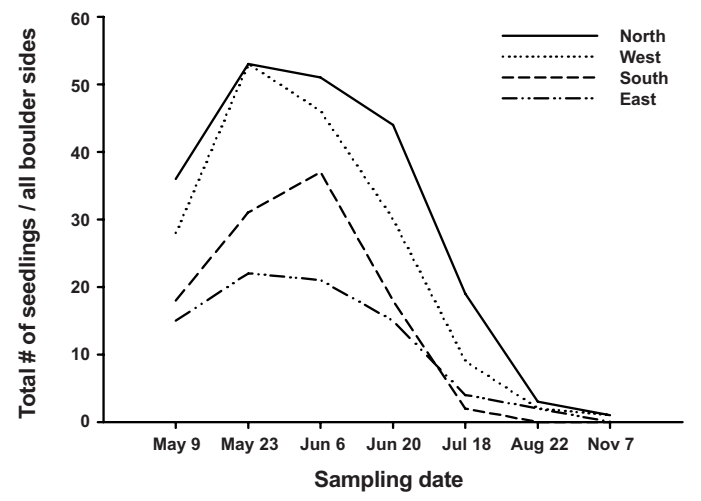

Fig. 1. The total number of hackberry seeds that germinated and seedlings that survived to be counted on 7 sampling dates in 2016. Hackberry seeds were planted on the north, west, south, and east sides of 26 boulders in the foothills of the Wasatch Mountains east of Provo, Utah, in October 2014. The total numbers of seedlings on each boulder side differed statistically on all sampling dates through 18 July 2016. See Table 1.

boulder. When appropriate, we used chisquare tests in JMP Version 12.1.0 (SAS Institute, Inc. 2015) to statistically test for patterns of germination.

On 9 May 2016, the overall rate of germination was very low. Ninety-seven (3.8\%) of the 2545 two-year-old seeds had germinated and survived to be counted. The germination rate was statistically higher on the north (5.7\%) sides and lower on the west (4.4\%), south $(2.8 \%)$, and east $(2.3 \%)$ sides of boulders (Table 1, Fig. 1). By 23 May 2016, the overall germination rate increased to $6.3 \%$ with a total of 159 seeds germinating. Germination rates were statistically higher on the north and west $(8.4 \%)$ sides than on the south $(4.9 \%)$ or east (3.4\%) sides of boulders (Table 1, Fig. 1). On 6 June 2016, the overall germination rate $(6.1 \%)$ was similar to the previous sampling date and germination rates were statistically higher on the north $(8.1 \%)$ sides of boulders than on the west $(7.3 \%)$, south $(5.8 \%)$ or east $(3.2 \%)$ sides (Table 1, Fig. 1). This pattern persisted and was statistically significant on 20 June, and 18 July 2016 as well (Table 1, Fig. 1). By 22 August 2016, only 7 seedlings had survived, and by 7 November 2016, only 2 seedlings remained (Table 1, Fig. 1).

Although still very low, it is interesting that germination rates 2 years after planting $(6.3 \%)$ were higher than rates one year after planting (2.1\%; Stevens et al. 2016). Bonner (1974) recommended running germination trials on Celtis for 90 days. Our study is the first of which we are aware to test germination over multiple years. Perhaps the low rates of germination observed for hackberry are due to the relatively long time frame required for germination to occur.

For multiple sampling dates in the spring and into summer, we found the highest germination rates on the north sides of boulders. This is surprising because multiple studies of mature hackberry shrubs have shown that the plants more frequently grow on sites with southern exposures (Tisdale 1986, DeBolt and McCune 1995a) and on the south sides of boulders (Argyle and Stevens 2013). So why does a shrub that grows in sunny areas in the Northern Hemisphere have higher germination rates on the comparatively shady north sides of boulders as we observed? Another study of hackberry germination (Stevens et al. 2016) indicated a similar pattern of germination, with higher rates on the north sides of boulders and especially low rates on the east sides of boulders after one year. These departures from the distribution patterns observed in mature hackberry populations (Tisdale 1986, DeBolt and McCune 1995a, Argyle and 
Stevens 2013) could be due to short-term, yearto-year variation in weather that happened to have a similar effect over the course of 2 years. However, the direction of the departures is consistent with the long-term effects of climate change shifting the distribution of hackberry to sites that are cooler and moister.

In western North America (Fettig et al. 2013), and especially in southwestern North America (Seager et al. 2007), climate change has brought about both warmer and drier conditions. What was once a more favorable site with southern exposure for hackberries to germinate and grow may be too hot and dry to allow for high germination rates under current conditions. Hackberry and other members of the northern mountainbrush community (Van Buren et al. 2011) in the Wasatch Mountain foothills may be particularly susceptible to the warming and drying brought about by climate change because the foothills in this area have historically been warmer and drier than the valleys at the base of the mountains, even though the foothills are at a higher elevation (Hayward 1948).

Further, in response to climate change, 2 congeners of $C$. reticulata (C. occidentalis and $C$. laevigata) have respectively been predicted to have a relatively large shift northward and a relatively large range reduction in response to climate change, compared to other North American trees (McKenney et al. 2007). In our study, $C$. reticulata may be simultaneously showing both of these climate change effects. On a microclimate scale, the seedlings in our study showed a northward shift by germinating on the north sides of boulders in relatively large numbers and a range reduction as these seeds (as well as those on other sides of boulders) failed to establish in the long-term.

We thank the students in the 2014 Plant Ecology class at Utah Valley University for collecting hackberry fruits, selecting boulders, and removing plant competition from around each boulder. We gratefully acknowledge Gary Stone and Daniel Smith for allowing us to undertake this study on their private land. Comments from an anonymous reviewer improved the manuscript.

\section{Literature Cited}

Argyle, A., AND M.T. Stevens. 2013. Influence of boulders on netleaf hackberry (Celtis reticulata) growth and distribution in the Wasatch foothills. Western Northern American Naturalist 73:525-529.

Bonner, F.T. 1974. Celtis L. hackberry. Pages 298-300 in C.S. Shopmeyer, compiler, Seeds of woody plants in the United States. Handbook 450, U.S. Department of Agriculture, Washington, DC.

DeBolt, A.M., And B. McCune. 1995a. Ecology of Celtis reticulata in Idaho. Great Basin Naturalist 55: 237-248.

DeBolt, A.M., And B. McCune. 1995b. Is netleaf hackberry a viable rehabilitation species for Idaho rangelands? Pages 305-309 in B.A. Roundy, E.D. McArthur, J.S. Haley, and D.K. Mann, compilers, Proceedings: Wildland Shrub and Arid Land Restoration Symposium. General Technical Report INT-GTR-315, U.S. Department of Agriculture, Ogden, UT.

Fettig, C.J., M.L. Reid, B.J. Bentz, S. Sevanto, D.L. SpitTLEHOUSE, AND T. WANG. 2013. Changing climates, changing forests: a western North American perspective. Journal of Forestry 111:214-228.

HaYWARD, C.L. 1948. Biotic communities of the Wasatch chaparral, Utah. Ecological Monographs 18:473-506.

McKenney, D.W., J.H. Pedlar, K. Lawrence, K. CampBELL, AND M.F. HutCHINSON. 2007. Potential impacts of climate change on the distribution of North American trees. BioScience 57:939-948.

SAS Institute, Inc. 2015. JMP Version 12.1.0. SAS Institute, Inc., Cary, NC.

Seager, R., M. Ting, I. Held, Y. Kushnir, J. Lu, G. Vecchi, H.-P. Huang, N. Harnik, A. LeetmaA, N.-C. Lau, et AL. 2007. Model projections of an imminent transition to a more arid climate in southwestern North America. Science 316:1181-1184.

Stevens, M.T., D.L. Holland, and N.V. Tanner. 2016. Netleaf hackberry seeds planted near boulders in the foothills of the Wasatch Mountains: germination, survival, and patterns of establishment. Western North American Naturalist 76:452-458.

TisDale, E.W. 1986. Canyon grasslands and associated shrublands of west-central Idaho and adjacent areas. Bulletin No. 40. Forest, Wildlife and Range Experiment Station, University of Idaho, Moscow, ID.

Van Buren, R., J.G. Cooper, L.M. Shultz, and K.T. HARPER. 2011. Woody plants of Utah: a field guide with identification keys to native and naturalized trees, shrubs, cacti, and vines. Utah State University Press, Logan, UT.

Received 28 February 2017 Accepted 16 May 2017 Published online 19 July 2017 